\title{
EKWIWALENCJA POLSKICH I JAPOŃSKICH TERMINÓW PRAWNYCH W PRAWIE CYWILNYM
}

\author{
Yuki HORIE, dr \\ Instytut Językoznawstwa, Wydział Neofilologii \\ Uniwersytet im. A. Mickiewicza \\ Al. Niepodległości 4, 61-874 Poznań \\ pupu@amu.edu.pl
}

\begin{abstract}
Abstrakt: W tym artykule terminologia występująca w polskim i japońskim prawie cywilnym została podzielona na cztery grupy: i) terminy posiadające ekwiwalenty o tym samym znaczeniu; ii) terminy $\mathrm{w}$ postaci hiperonimów lub hiponimów; iii) terminy posiadające ekwiwalenty, odnoszące się do nieco innej rzeczywistości; oraz iv) terminy, w których brak jest odpowiednich ekwiwalentów. Celem niniejszego artykułu jest ukazanie trudności związanych z przekładem tej terminologii, jak i poruszenie zagadnień odnoszących się do terminologii wykorzystanej na sali sądowej, a różnej w obu tych krajach.
\end{abstract}

Słowa kluczowe: system przysposobienia zwykłego, system przysposobienia specjalnego, japoński Kodeks Cywilny, polski Kodeks Cywilny, ekwiwalencja

\section{ポーランドと日本の民法用語における等価性の問題について}

\begin{abstract}
Abstrakt: 日本語とポーランド語のエキバレンスを考察すると、一見したところエキバ レンスが意味する対象物は同じであるように見えるが、よく内容を比較すると重要な違 いや意味合いのずれが生じているものがある。この論文では、ポーランドと日本の民法 に登場する法律用語を比較し、エキバレンスの対象物が同等であるもの、エキバレンス の意味する対象にずれがあるもの、エキバレンスの一方が広義または狭義であるもの、 そしてエキバレンスが対応言語に存在しないものの 4 つの区分に分けて論じたいと思う。
\end{abstract} Slowa kluczowe: 普通養子制度、特別養子制度、日本の民法、ポーランドの民法、等価性

\section{AN EQUIVALENCE STUDY OF POLISH AND JAPANESE TERMS IN CIVIL LAW}

\begin{abstract}
Comparing the terminology in Polish and Japanese civil law, it can be divided into the following four groups; the first group, in which there are equivalents in both languages with the same meaning; the second group, in which the equivalents exist, but in one language the semantic field is wider; the third group, in which the equivalents exist, but their semantic fields to some extent are not identical; and the last one, in which there are no equivalents. In this article I would like to analyze the Polish-Japanese legal terminology in accordance with that division into four groups.
\end{abstract}

Key words: general adoption system, special adoption system, Japanese Civil Code, Polish Civil Code, equivalent

\section{Wstęp}

Tytułem wstępu do zagadnienia ekwiwalencji chciałabym rozpocząć od zagadki z zakresu językoznawstwa. Biegacze A i B ścigali się ze sobą w Polsce i w Japonii. Załóżmy, że obaj biegali $\mathrm{z}$ taką samą prędkością $10 \mathrm{~km}$ na godzinę. Biegacz 
Yuki Horie, Ekwiwalencja polskich i japońskich terminów prawnych...

A wystartował w wejściu do budynku i wbiegł na trzecie piętro. Biegacz B zaczął w tym samym punkcie, zbiegł jednak trzy piętra w dół. W Polsce rywalizacja obu biegaczy skończyłaby się remisem, w Japonii jednak zwycięzcą zostałbym zawodnik A. Jaka jest tego przyczyna?

Ta zagadka wydaje się na pierwszy rzut oka nie mieć nic wspólnego z językoznawstwem. Jednak, aby poznać jej rozwiązanie, należy zrozumieć, co jest desygnatem japońskiego ,pierwsze piętro” (j. ikkai 一階) i polskiego „parter”. A zwyciężył z B właśnie dlatego, że japońskie „pierwsze piętro” odpowiada polskiemu „parterowi”, zatem w Japonii wejście do budynku znajdowało się na pierwszym piętrze. Biegacz A musiał wbiec tylko dwa piętra, zaś biegacz B był zmuszonyzbiec o trzy kondygnacje niżej. Jeżeli zatem japońskie ikkai przełożymy dosłownie jako „pierwsze” (j. ichi一) ,piętro” (j. kai 階), wywołamy nieporozumienie. W tym przypadku widać, że choć istnieje ekwiwalencja w obu tych językach, to desygnat odpowiadających sobie wyrazów może być różny; taka sytuacja wymaga zupełnie innego traktowania, anieżli sytuacje, w których desygnaty są takie same, (np. japońskie kompyūta コンピュータ i polski „komputer”).

Istnieją również przypadki, w których zakres ekwiwalencji w jednym z dwóch porównywanych języków jest znacznie szerszy lub węższy. Na przykład według Słownika języka polskiego „ryż” to: „1. Oryza, roślina zbożowa z rodziny traw, występująca w wielu gatunkach na obszarach tropikalnych i subtropikalnych; najbardziej znany ryż siewny, uprawiany dla celów konsumpcyjnych, służący także do wyrobu alkoholu; słoma używana jako pasza oraz do wyplatania mat. kapeluszy itp.; 2. Ziarno tej rośliny oraz potrawa przyrządzana z tych ziaren”. W definicjach tych nie ma mowy o tym, czy ów „ryż” można zjeść czy nie. Można kupić „ryż” w supermarkecie i zjeść go na kolację. W Japonii jednak w supermarkecie kupuje się kome 米, a na kolację je gohan ご飯. Innymi słowy wedle Shin meikai kokugo jiten (新明解国語辞典 , Nowy słownik języka japońskiego z jasnymi objaśnieniami) ,ważne ziarno ryżu będące podstawowym pokarmem Japończyków" to kome, ,jedzenie z ugotowanego m.in. kome” to meshi 飯 lub gohan. W tym przypadku znaczenie polskiego słowa „ryż” jest znacznie szersze niż któregokolwiek z jego japońskich odpowiedników. Zjawisko to nie ogranicza się do rzeczowników. Przykładowo czasownik arau 洗う w tym samym słowniku zdefiniowany jest: „usuwanie zabrudzeń przez polanie wodą lub środkami chemicznymi". Przedmiotem czynności są wszystkie zabrudzenia, i te znajdujące się na ciele, i te na ubraniach lub ziemniakach. W polskim rozróżnienie na „myć” i „prać” od razu wprowadzi pewne rozgraniczenie co do przedmiotu czynności. „Myć” to, znów za Słownikiem języka polskiego, „usuwać brud za pomocą wody, mydła, środków chemicznych szczotek itp.”, „prać” zaś to „usuwać brud z tkanin (bielizny, odzieży itp.) za pomocą wody z dodatkiem środków rozpuszczających brud, np. mydła, proszków, płynów; usuwać zanieczyszczenia $\mathrm{z}$ tkanin za pomocą środków chemicznych np. benzyny".

W polskim i japońskim istnieją oczywiście wyrazy nieposiadające swoich ekwiwalentów. Najczęściej są to słowa związane z lokalną kulturą i tradycją. Na przykład niezwykle trudno będzie przełożyć na japoński wyraz „oscypek”, nazwę góralskiego sera. Będzie to musiało być raczej omówienie, na przykład: „wędzony ser będący specjalnością polskich górali, bardziej słony i nieco twardszy od zwykłego 
sera”. Z drugie strony przykładowo termin shichigosan 七五三 będzie bardzo trudny do przetłumaczenia na polski. „Święto obchodzone 15 listopada przez chłopców w wieku 3 i 5 oraz dziewczynki w wieku 7 lat, podczas którego wkłada się tradycyjne stroje i udaje z modłami do shintoistycznego bóstwa rodowego" - byłoby zapewne optymalnym przekładem.

Poniżej chciałabym dokonać analizy terminologii prawnej z zakresu prawa cywilnego dzieląc ją na cztery grupy: 1. terminy, w przypadku których istnieje ekwiwalencja, desygnaty zaś są takie same; 2. terminy, w przypadku których istnieje ekwiwalencja, desygnaty zaś różnią się; 3. terminy, w przypadku których występują ekwiwalenty, mają one jednak w jednym z języków szersze lub węższe znaczenie; 4. wyrazy, w przypadku których nie zachodzi ekwiwalencja i konieczne jest dokonywanie przekładów objaśniających.

Językami będącymi przedmiotem niniejszego artykułu są polski i japoński. Przede wszystkim w rejestrze stosowanym w dokumentach prawnych, jako hōritsu yōgo (法律用語, ,język prawny”) oraz we wszelkich innych rejestrach mających związek $\mathrm{z}$ prawem formułowanym $\mathrm{w}$ języku prawniczym. W języku prawnym zawarta jest terminologia prawna.

Z punktu widzenia prawa niniejszej pracy za swój główny temat ma ekwiwalencje terminów prawa cywilnego, co w warunkach prawa polskiego oznacza skupienie się na Kodeksie cywilnym oraz Kodeksie rodzinnym i opiekuńczym ${ }^{1}$.

W prawie japońskim odpowiada im Minji hōten (民事法典, dosł.: Kodeks spraw cywilnych). Stosowane odtąd określenia ,kodeks cywilny” i mimpō (民法， „prawo cywilne”) wskazuje więc na taki zakres przepisów prawnych w Polsce i Japonii. Ponadto w kwestiach związanych z przebiegiem postępowania cywilnego wzięte pod uwagę zostaną również przepisy polskiego Kodeksu postępowania cywilnego oraz japońskiego Minji soshōhō (民事訴訟法, Ustawa o postępowaniu $w$ sprawach cywilnych).

\section{Słowa posiadające ekwiwalenty o tym samym znaczeniu funkcjonujące w taki sam sposób w obu krajach}

\subsection{Shizenjin (自然人, „osoba fizyczna”) i hōjin (法人, „osoba prawna”)}

Oba te terminy w japońskim i polskim mają identyczne desygnaty. W japońskim są to wyrazy utworzone w okresie Meiji (1868-1912), kiedy modernizująca się Japonia tworzyła własne prawo cywilne wzorowane na niemieckim. Dlatego terminy te posiadają swoje ekwiwalenty w języku polskim, brzmią jednak obco dla przeciętnego

\footnotetext{
${ }^{1}$ Pojęcie sprawy cywilnej niniejszej pracy ograniczone są do spraw wynikających z kodeksu cywilnego z znaczeniem ścisłym materialno-prawnym. Według kodeksu postępowania cywilnego (tytuł wstępny Art. 1), pojęcia sprawy cywilnej są sprawami z zakresu prawa cywilnego, rodzinnego i opiekuńczego oraz prawa pracy, jak również $\mathrm{w}$ sprawach $\mathrm{z}$ zakresu ubezpieczeń społecznych oraz $\mathrm{w}$ innych sprawach, do których przepisy Kodeks postępowania cywilnego stosuje się z mocy ustaw szczególnych, jak na postępowanie rozpoznawania protestów wyborczach, w sprawach ze stosunków cywilnych między przedsiębiorcami, w zakresie prowadzonej przez niech działalności gospodarczej. Aczkolwiek wyżej wymienione sprawy nie są przedmiotami głównymi w rozważanej pracy.
} 
Yuki Horie, Ekwiwalencja polskich i japońskich terminów prawnych...

Japończyka i stosowane są niemal wyłącznie przez osoby zajmujące się prawem. Owa „obcość” wynika z połączenia słów shizen (natura), ho (prawo) i jin (,człowiek”).

Złożenie shizen ma wiele znaczeń, które można podzielić na trzy następujące grupy;

i) Ciała niebieskie, góry, rzeki, drzewa, to, co otacza społeczność ludzi. W takim znaczeniu antonimem jest bunka (文化, „kultura”).

ii) Stan lub natura, które nie zostały zniekształcone lub zniszczone, „,naturalny”. W takim znaczeniu antonimem jest jinkō (人工, „sztuczny”).

iii) Zaistnienie jakiejś sytuacji nie poprzez starania lub celowość. Dojście do jakiegoś stanu na skutek działania instynktu lub naturalnych przemian fizycznych. W takim znaczeniu antonimem jest fushizen（不自然， ,nienaturalny").

Element shizen w złożeniu shizenjin odpowiada drugiemu znaczeniu.

Z drugiej strony ideogram $h \bar{o}$ (法) w złożeniu hōjin ma trzy znaczenia;

i) $\quad \mathrm{W}$ szerokim znaczeniu jest to rodzaj norm społecznych oddzielnych od moralności.

ii) Ogólna, abstrakcyjna norma określająca prawa i obowiązki.

iii) Forma prawa państwowego uchwalona przez parlament. W Japonii przepisy zatwierdzone przez parlament nazywa się hōritsu.

Element $h \bar{o}$ w hōjin odpowiada trzeciemu z powyższych znaczeń.

$H o \overline{~ n i e ~ j e s t ~ w i e ̨ c ~ d l a ~ p r z e c i e ̨ t n e g o ~ u z ̇ y t k o w n i k a ~ j a p o n ́ s k i e g o ~ n a t u r a l n y m ~}$ antonimem shizen. Ponadto jin w codziennym japońskim to „człowiek”, ,jednostka składająca się na społeczeństwo” lub „natura człowieka”, nie zaś instytucja usytuowana poza człowiekiem i jego naturą, jak w terminie hōjin.

\subsection{Hōritsu kōi (法律行為, „czynność prawna”) i ishi hyōji (意思表示, „wyrażenie woli'”)}

Czynność prawną uznać można za jeden z najważniejszych terminów prawa cywilnego. Oznacza on konieczne warunki prawne niezbędne do powstania określonego skutku prawnego. Koniecznym elementem czynności prawnej jest wyrażenie woli. Hōritsu kōi jest przekładem niemieckiego terminu Rechtsgeschäft. Nie jest to zwrot powszechnie używany; jest to raczej zwrot specjalistyczny poznawany podczas studiów prawa. Składa się on ze słów ,prawo” (j. hōritsu) i „czynność” (j. kōi 行為).

W klasycznych tekstach chińskich złożenie $k \bar{o} i$ zapisywane było ideogramami 行䋒 (ch. xingwei) i oznaczało „czyn”, „postępowanie”. Użycie takie pojawia się już u chińskiego myśliciela konfucjańskiego Xunzhi (j. Junshi, 298?.-po 238 p.n.e.). Jednak termin ten $\mathrm{w}$ japońskim prawie cywilnym pojawił się jako przekład niemieckiego wyrażenia prawnego. W niemieckim funkcjonują jako synonimy wyrazy „Ereignis” i „Verhalten”, z których pierwszy oznacza „wydarzenie”, drugi zaś „zachowanie”. Te z kolei rozróżnia się na „zachowanie wewnętrzne” (inneres Verhalten) i „zachowanie zewnętrzne” (außeres Verhalten), nazywane również „Handlung”. W kodeksie cywilnym owo Handlung zostało przetłumaczone jako „czyn zgodny z prawem” (j. jun hōritsu $k \bar{o} i$ 準法律行為), różny od „czynności prawnej”. Różnica między oboma pojęciami tkwi w obecności lub braku woli. Jeżeli wolna wola nie zostaje wyrażona, 


\section{Comparative Legilinguistics 17/2014}

czyn może być zgodny z prawem, jeżeli jednak zostaje wyrażona na zewnątrz w postaci na przykład umowy lub testamentu, mamy do czynienia z czynnością prawną (Huruta 2005: 57-71).

Niezbędne do zaistnienia czynności prawnej „wyrażenie woli” składa się z terminów ishi (意思, „wola”) i hyōji (表示, ,wyrażenie”).

Obok powyżej wspominane ishi (odtąd $i s h i^{*}$ ) istnieje również homofon zapisywany 意志 (odtąd $i s h i^{* *}$ ), którego znaczenie jest bardzo zbliżone do $i s h i^{*}$ i który częściej występuje w powszechnym użyciu. Ściśle rzecz biorąc $i s h i^{* *}$ oznacza stan umysłu, w którym człowiek pragnie dokonać czegoś, $i s h i^{*}$ zaś to stan myśli lub uczuć; ish ${ }^{*}$ występuje często jako termin prawniczy. Ishi** to stare słowo używane od czasów dynastii Wczesnej Han (202 p.n.e.-9 n.e.) w znaczeniu „serce”, „myśl” i jako takie wcześnie trafiło do języka japońskiego. Ishi* to dziewiętnastowieczne chińskie tłumaczenie angielskiego will i motive wykorzystane przez Japończyków. $\mathrm{W}$ późniejszym okresie $i s h i^{* *}$ posługiwano się $\mathrm{w}$ filozofii i psychologii, ishi* zaś w prawie.

Hyōji jest przekładem niemieckiego „Erklärung”. Termin ten jednak może zostać przetłumaczony na najróżniejsze sposoby, jako np. „objaśnienie” (j. setsumei 説 明), „wyraz” (j. hyōmei 表明), „ogłoszenie [np. wyroku]” (j. senkoku 宣告), „deklaracja” (j. sengen 宣言), ,proklamacja” (j. fukoku 布告) i „wyznanie” (j. kokuhaku 告白).

Jest to termin, który $\mathrm{w}$ japońskim oddawany jest różnymi złożeniami w zależności od kontekstu. Złożenia ideogramów są jednak postrzegane przez Japończyków jako „trudne do zrozumienia” i „formalne”, stąd w języku mówionym preferuje się rodzime słowa japońskie.

Ishi* jest przekładem angielskiego will, który to wyraz jest również czasownikiem. Z kolei $i s h i^{*} \mathrm{i} i s h i^{* *}$ są tylko rzeczownikami ${ }^{2}$. Przyczyną tego jest fakt, że w języku japońskim nie ma zwyczaju wyrażać własnej woli, zaś cechą charakterystyczną jego gramatyki jest znacznie rzadsze niż na przykład w angielskim stosowanie formy analogicznej do will. Innymi słowy na płaszczyźnie językowej odbicie znajduje pewna niechęć kultury japońskiej do otwartego wyrażania woli jednostki (Furuta 2005: 43-55).

\section{Istnieje ekwiwalencja, funkcje terminów jednak różnią się}

\subsection{Seinen (成年, ,pelnoletni”)}

Chciałabym porównać następujące zdania:

1. On pije alkohol, ponieważ ma 18 lat.

2. On pije alkohol, mimo iż ma 18 lat.

Według polskiego Kodeksu cywilnego w art. $10 \S 1$ stanowi, że pełnoletnim jest ten, kto ukończył lat 18. Daje ono możliwość dokonywania czynności prawnych samodzielnie. Tj. bez zgody przedstawicieli ustawowych (Encyklopedia prawo 2001: 412-413).

Z drugiej strony wedle art. 4 japońskiego Kodeksu cywilnego osoba pełnoletnia

\footnotetext{
${ }^{2}$ Wyrażenia ishi* suru lub ishi** suru (dosłownie: „robię ishi”), całkowicie poprawne gramatycznie, są dosłownym tłumaczeniami, bardzo nienaturalnymi w codziennym języku.
} 
Yuki Horie, Ekwiwalencja polskich i japońskich terminów prawnych...

to taka, która ukończyła 20 rok życia. Innymi słowy istnieje ekwiwalent słowa „pełnoletni”, ale w obu krajach ów wiek, który staje się „pełny”, różni się. Stąd pierwsze zdanie odnosi się do prawa polskiego, drugie zaś do japońskiego.

Porównajmy inne terminy odnoszące się do poszczególnych etapów w rozwoju człowieka. „Małoletni”, wedle Encyklopedii prawa, to „według polskiego Kodeksu cywilnego (...) osoba, która nie ukończyła 18 lat i nie zawarła związku małżeńskiego. Osoba małoletnia albo nie posiada zdolności do czynności prawnych (do 13 roku życia), albo posiada ją w stopniu ograniczonym (między 13 a 18 rokiem życia, chyba że jest całkowicie ubezwłasnowolniona, wówczas nie posiada jej wcale)" (Adynowska 2001, 304-305). Ekwiwalentem terminu „małoletni” jest japońskie 未成年者 miseinensha, ale w japońskim prawie cywilnym jego zdolność do czynności prawnych uznana jest za niedoskonałą i, wraz $\mathrm{z}$ m.in. osobami ubezwłasnowolnionymi całkowicie (j. $h i$ kōkennin, 被後見人), uznany on jest za „osobę o ograniczonej zdolności prawnej” (j. seigen kōi nōryokusha, 制限行為能力者).

Obok terminu „małoletni” istnieje też wyraz „nieletni”. Pojęcie nieletniego jest pojęciem z zakresu prawa karnego. Pojęcia to określa ustawa o postępowaniu w sprawach nieletnich i odwołuje się do niej Kodeks karny. Tak więc nieletni to:

i) $\quad \mathrm{w}$ zakresie zapobiegania $\mathrm{i}$ zwalczania demoralizacji jest osoba, która nie ukończyła 18 lat.

ii) $\mathrm{W}$ zakresie postępowania o czyny karalne (przestępstwa i niektóre wykroczenia) jest osoba między 13 a 17 rokiem życia.

iii) w przypadku orzeczonych już środków wychowawczych lub poprawczych jest osoba do 21 roku życia.

$\mathrm{Z}$ drugiej strony w prawie japońskim istnieją takie terminy określające osoby o młodym wieku, jak na przykład shōnen (少年, dosł.: „młody wiek”), jidō (児童, dosł.: „dziecko”) i nenshōsha (年少者, dosł.: „osoba o niższym wieku”), nie jest jednak jednoznaczne, jaki zakres wiekowy określają. Rozumienie tych terminów musi zatem postępować za aktami prawnymi, w których występują. Na przykład shōnen w art. 2 Ustawy o młodocianych (j. Shōnenhō, 少年法) określony jest jako osoba poniżej 20 roku życia, jednak w art. 4 Ustawy o opiece społecznej nad nieletnimi (j. Jidō fukushihō, 览童福祉法) jako osoba od rozpoczęcia edukacji w szkole podstawowej do 18 roku życia. W art. 4 tej samej ustawy jidō zdefiniowany jest jako osoba poniżej 18 roku życia, w Podstawowym prawie pracy (j. Rōdō kijunhō, 労働基準法) jednak jako osoba młodsza niż 15 lat (czyli osoba, która nie ukończyła edukacji obowiązkowej). Jednak w art. 26 Ustawy o edukacji szkolnej (j. Gakkō kyōikuhōo, 学校教育法) jidō oznacza osobę uczęszczającą do szkoły podstawowej, art. 6 Ustawy o opiece społecznej nad matkami i dziećmi oraz wdowami (j. Boshi oyobi kafu fukushihō, 母子及び寡婦福祉法 ) ten sam termin oznacza osobę niepełnoletnią, tzn. taką, która nie ukończyła 20 roku życia. Nenshōsha w podstawowym prawie pracy ma mniej niż 18 lat, w przeciwieństwie do miseinensha, zdefiniowanego, jak wspomniano, na początku Kodeksu cywilnego jako osoba młodsza niż 20 lat. 


\section{Slowa posiadające ekwiwalenty, których pole semantyczne w jednym języku jest szersze lub węższe niż w drugim}

\subsection{Yōshi (養子, ,przysposobienie”)}

Porównajmy poniższe zdania:

1. On spędził dzieciństwo w domu dziecka. $\mathrm{W}$ wieku 10 lat został przysposobiony przez małżeństwo Nowaków.

2. Po ślubie on zmienił nazwisko na żony, ponieważ został przysposobiony jako zięć.

Zdanie $1 \mathrm{z}$ pewnością nie sprawi problemów. W drugim jednak zdziwienie muszą budzić dwa występujące razem elementy: „po ślubie” i „przysposobiony”. W Japonii jednak nierzadko dorośli mężczyźni (mężczyźni w Japonii mogą zawierać związki małżeńskie od 18 roku życia. W przypadku zawarcia związku małżeńskiego przez niepełnoletniego, po zawarciu małżeństwa jest on uznawany za pełnoletniego) zostają przysposobieni przez rodziców żony. W Japonii oprócz przysposobienia, które w wielu aspektach jest identyczne z polskim, również istnieje tradycyjny system adopcji, mający zapewnić trwanie rodziny w linii męskiej. To przysposobienie tradycyjne oparte jest na przywiązywaniu przez Japończyków wielkiej wagi do zachowania ciągłości istnienia rodziny, rodu. Na przykład jeżeli małżeństwo ma jedną córkę, może przysposobić np. swojego wnuka. Co prawda w związku $\mathrm{z}$ obecnymi zmianami w systemie prawa rodzinnego, pochodzącego z okresu, gdy powstawała konstytucja Japonii, coraz słabsza jest determinacja w podtrzymywaniu systemu ie 家, również współcześnie dochodzi często do wykorzystywania adopcji, np. przysposabia się wnuki celem zmniejszenia podstawy opodatkowania spadkowego ${ }^{3}$. Innymi słowy cechą charakterystyczną japońskiego systemu przysposobienia (j. yōshi seido, 養子制度) jest prawna możliwość adoptowania osób dorosłych, zamężnych/żonatych lub krewnych.

We współczesnej Japonii na przysposobienie składają się dwa typy: tzw. „przysposobienie zwykłe” (j. futsū yōshi seido, 普通養子制度), w którym rodzic i przysposobione „dziecko" zawiązują tylko rodzaj umowy adopcyjnej, oraz tzw. „przysposobienie specjalne” (j. tokubetsu yōshi seido, 特別養子制度), w którym relacja przysposobienia powstaje poprzez decyzję instytucji publicznej jaką jest sąd, celem opieki nad dzieckiem (np. sierotą) i wychowania go.

Relację przysposobienia zwykłego, jak wspomniano powyżej, można zawiązać $\mathrm{w}$ razie istnienia woli obu stron. Jeżeli przewidziane dokumenty zostaną złożone w urzędzie właściwym dla rejestru rodzinnego osoby zgłaszającej lub dla jej miejsca zamieszkania, od tego dnia zawiązana zostaje relacja przysposobienia, następnie zaś dokonywany jest odpowiedni wpis do rejestru rodzinnego.

Przysposobienie specjalne rozpoczyna się od rejestracji w publicznej lub prywatnej organizacji pośredniczącej. Tam rodzice adopcyjni są sprawdzani pod względem wieku i innych warunków ${ }^{4}$. Jeżeli wszystkie warunki zostaną spełnione,

\footnotetext{
${ }^{3}$ Obecnie, po nowelizacji prawa podatkowego, jeżeli ma się własne dzieci, możliwa jest adopcja jednej osoby, jeżeli dzieci się nie ma, dwóch osób.

${ }_{4}^{4}$ Również warunki, jakie spełnić muszą przysposabiający, są surowsze niż w przypadku przysposobienia zwykłego:
} 
Yuki Horie, Ekwiwalencja polskich i japońskich terminów prawnych...

dokonywana jest rejestracja osób pragnących zostać rodzicami adopcyjnymi. Następnie, jeżeli zostanie znalezione niemowlę, które może zostać przysposobione, składa się odpowiedni wniosek do sądu rodzinnego. Najpierw rodzice adopcyjni wnoszą o otrzymanie z sądu rodzinnego specjalnego wniosku o zawiązanie specjalnej relacji przysposobienia, do którego dołączają odpis rejestru rodzinnego swojego, rodziców lub opiekuna prawnego oraz kopie zaświadczenia o zameldowaniu swoje, przysposabianego, rodziców lub opiekuna prawnego. Rodzice biologiczni osobno składają W sądzie rodzinnym pisemną zgodę na przysposobienie specjalne. Po zakończeniu tego etapu procedury przysposabiany zostaje powierzony przysposabiającym na sześciomiesięczny okres próbny, aby sąd rodzinny mógł zadecydować, czy przysposabiający $\mathrm{w}$ praktyce sprawdzają się jako rodzice. Po zakończeniu owego okresu próbnego przysposabiający otrzymują z sądu odpis orzeczenia sądu rodzinnego o zawiązaniu przysposobienia specjalnego oraz dokument potwierdzający pozytywne przejście okresu próbnego. Następnie przysposabiający mają obowiązek udać się z tymi dokumentami do urzędu rejestracyjnego celem wpisania odpowiednich danych do rejestru.

Przysposobienie według polskiego Kodeksu cywilnego orzeka sąd rodzinny po uprzednim ustaleniu, że między dzieckiem a przyszłymi rodzicami istnieje stosowna różnica wieku, że są oni w stanie zapewnić mu właściwe warunki materialne i że dają na przyszłość gwarancję właściwego wychowania, $\mathrm{z}$ reguły lepszego niż dotychczasowe. Głównym celem przysposobienia powinno być zapewnienie pełnej rodziny dziecku pozbawionemu obojga lub jednego z rodziców. Dlatego też Kodeks rodzinny $i$ opiekuńczy stanowi, że przysposobić można tylko osobę małoletnią i tylko dla jej dobra. Oznacza to, że nie można przysposobić osoby, która ukończyła 18 rok życia (Encyklopedia prawa 2001:526-527).

\section{Brak ekwiwalentu w jednym z języków}

Jeżeli brak jest ekwiwalentów, to w języku docelowym musimy zdecydować się na najbliższe możliwe słowo, potraktowanie terminu $\mathrm{z}$ języka źródłowego jako zapożyczenia lub posłużenie się wyjaśnieniem. Poniżej przedstawiono kilka przykładów tego typu słów. Braki ekwiwalentów występują szczególnie w japońskiej terminologii $\mathrm{z}$ zakresu rejestru rodzinnego.

i) Przysposabiający muszą być małżeństwem i oboje małżonków stają się przysposabiającymi (Art. 817 Par. 3).

ii) Jedno z przysposabiających musi mieć ponad 25 lat, drugie zaś ponad 20 lat (Art. 817 Par. 4).

Ponadto przysposabiający obserwowani są przez sześciomiesięczny okres próbny przez organizację pośredniczącą $\mathrm{W}$ adopcji, np. poradnia psychologiczno-pedagogiczna, wyniki obserwacji zaś przekazywane są sądowi rodzinnemu (Art. 817 Par. 8). Ponadto publiczne instytucje adopcyjne określają, że przysposabiający muszą mieć mniej niż 60 lat, ich mieszkanie musi mieć co najmniej dwa pomieszczenia i każdy ma ok. $17 \mathrm{~m}^{2}$ powierzchni, kuchnia musi być oddzielona od reszty mieszkania, zaś przysposabiający muszą móc poświęcić się opiece nad przysposobionym. 
kyosho 居所- miejsce przebywania

Jeżeli miejsce zamieszkania nie jest ustalone, miejsce, w jakim przebywa dana osoba.

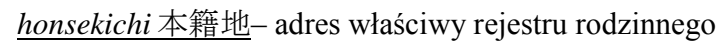

hittōsha 筆頭者- imię i nazwisko członka rodziny figurującego w rejestrze rodzinnym na pierwszym miejscu

zokugara 続柄- stosunek pokrewieństwa (chōnan 長男, ,najstarszy syn”, jinan 次 男, ,drugi syn” itd.)

jisshi 実子- rodzone dziecko

Jest to termin będący niejako antonimem yōshi, dziecka przysposobionego. Jisshi dzieli się na dzieci urodzone w małżeństwie i na urodzone poza nim.

yuinō 結 納 - ceremonialne wymienienie podarków przez narzeczonych oznaczające formalne zaręczyny

Przebieg samej ceremonii różni się w zależności od regionu Japonii, jednak zazwyczaj swat odbiera z domu narzeczonego prezenty (j. yuinōhin, 結納品) i zanosi je do domu narzeczonej, po czym zanosi do domu narzeczonego dary, którymi rewanżuje się rodzina przyszłej żony. Yuinōhin są sprzedawane w specjalnych zestawach w domach towarowych i kosztują obecnie od kilkudziesięciu do kilkuset tysięcy jenów. Wśród nich często znajdują się dobro wróżbne produkty żywnościowe, np. suchotki (j. awabi, 鮑 ), symbolizujące długie życie, kawałki suszonej ryby latającej (j. katsuobushi, 鰹節), symbolizujące męską siłę, suszona ośmiornica (j. surume, 鯣), oznaczająca długie szczęśliwe życie oraz wodorosty kombu (昆布), mające gwarantować liczne potomstwo.

\section{hōtei ketsuzoku 法定血族 - pokrewieństwo po przysposobieniu}

Również ten termin stanowi parę dla innego terminu prawnego, a mianowicie prawdziwego pokrewieństwa. Określa on relacje powstałe po przysposobieniu.

naien 内縁 - małżeństwo bez zgłoszenia zawarcia związku małżeńskiego

Według prawa japońskiego para, która złożyła Zawiadomienie o zawarciu związku małżeńskiego, może nazywać się małżeństwem, jeżeli zaś z jakiegoś powodu nie może lub nie chce złożyć takiego dokumentu, żyje jednak wspólnie jak małżeństwo, nazywa sie ją terminem naien. Związek taki jest chroniony prawnie w większym stopniu niż dōkyo (同居, „wspólne mieszkanie”) i dōsei (同棲, konkubinat) gdzie więź między mężczyzną a kobietą jest słabsza. 
Yuki Horie, Ekwiwalencja polskich i japońskich terminów prawnych...

rien 離縁 - rozwiązanie relacji przysposobienia

Pierwotne znaczenie tego słowa to ustanie relacji więzi między dwojgiem ludzi i w tym znaczeniu również rikon (離婚, ,rozwód”) jest rodzajem rien, jednak w prawie cywilnym termin ten odnosi się wyłącznie do relacji przysposobienia.

\section{Zakończenie}

„Właśnie złożyłem w urzędzie miasta zawiadomienie o rozwodzie. Tym samym dziś rozwiodłam się z mężem" - takie zdanie brzmieć musi obco w uszach Polaka. A to dlatego, że „rozwód”, „urząd” i „dziś” (jeden dzień) nie pasują do siebie w polskiej procedurze rozwodowej, która opiera się na rozprawie rozwodowej przed sądem. Jednakże w Japonii, gdzie taki rozwód za porozumieniem stron jest czyś powszechnym, zdanie takie mogłoby paść w zwykłej rozmowie. Widzimy zatem jak oczywista, wydawałoby się, ekwiwalencja 離婚 rikon= „rozwód” może powodować wiele nieporozumień, jeżeli niedostatecznie zrozumie się znaczenie tego terminu w obu tych językach.

W przypadku różnicy dotyczącej pięter, o której wspomniano na początku, niedostateczne zrozumienie różnicy znaczeniowej może doprowadzić co najwyżej do oczekiwania na kogoś na niewłaściwym piętrze. Terminologia prawna jest jednak wykorzystywana na sali sądowej. Jeżeli weźmiemy pod uwagę, że decyzje tam podejmowane mogą określić dalszy bieg czyjegoś życia, analiza tego typu różnic ekwiwalencji staje się niezwykle istotna.

Współcześnie, gdy świat się globalizuje, a ludzie różnych ras i narodowości przemierzają go bez przerwy, granice państw wydają się zanikać. W świecie prawa jednak, dla dobra nas wszystkich, potrzeba, aby granice, o których była mowa powyżej, stawały się coraz bardziej uświadamiane sobie i widoczne.

\section{Bibliografia}

Adynowska Barbara i inni, 2001. Encyklopedia prawo, Kraków: PPU Park.

Buczna Małgorzata, red., 2008. Kodeks cywilny, Kodeks rodzinny i opiekuńczy, Warszawa: Wolters Kluwer Polska.

Gōhara T. 2006. 民法 総則物件編 (Minpō sōsoku bukken hen). Tokyo: TAC syuppansya.

Gōhara T. 2006. 民法＼cjkstart債権編 (Minpō saiken hen). Tokyo: TAC syuppansya.

Okabe Atsushi, 2005, Saibansho no koto ga subete wakaru hon, Tokyo: Minzihō kenkyūkai.

Halpern J. 1995. New Japanese English Character Dictionary. Tokyo: Kenkūsha.

Hendry J. 1997. Understanding Japanese Society. Routledge.

Huruta A. 2001. 異文化コミュニケーションキーワード(Ibunka komyunikēsyon kīwādo). Tokyo:Yūsenkaku sōsyo.

Huruta H. 2005. 翻訳語としての日本の法律用語 (Honyakugo tositeno nihon no hōritu yōgo). Tokyo: Tyūō syuppanbu. 
Kenbō H. Kindaiti H. Sibata T. Yamada T. Kindaiti K. 1987. 新明解 国語辞典 (Simēkai kokugo ziten). Tokyo: Sansyōdō.

Kondō I. Takano H. (ed.) 1989. Progressive Japanese-English Dictionary. Tokyo: Shōgakukan.

Konisi Y. Yasui N. Kunihiro T. 1980. Progressive English-Japanese Dictionary. Tokyo: Shōgakukan.

Moriki Kazumi, 1997. Kokusai kekkon gaidobukku, Tokyo: Akasi shoten.

Okuta Yasuhiro, red., 2006. Kokusai sihō kokuseki hō kazoku hō shiryōshū, Tokyo: Chūōdaigaku shuppansha.

Ōmura A. 2007.「民法 O . 1.2．３条」＜私>が生きるルール (Minpō zero, iti, ni, san zyō. <Watasi> ga ikiru rūru). Tokyo: Misuzu syobō

Ozaki T. 2005. 法律英語用語辞典 (Hōritu ēgo yōgo ziten). Tokyo: Ziyūkokuminsya.

Saitō T. 2005. 明治の言葉 (Meiji no kotoba). Tokyo: Kōdansya gakuzyutu bunko.

Sotoyama S. 1976. 日本語の個性 (Nihongo no kosei). Tokyo: Tokyo Tyūō kōron.

Takanasi Kimiyuki, red., 2006. Kōgo roppō zensho kōgo mimpō, Tokyo: Ziyūkokuminsha.

Gōhara Toyoshige, 2006. Minpō no marugoto kōgi namachūkē, Tokyo: TAC.

Mroczkowska-Budziak Agnieszka, 2007. Seidel Ryszard, Elementy prawa, Poznań: Oficyna Edukacyjna Wydawnictwa eMPi².

http://www.moj.go.jp/ONLINE/FAMILYREGISTER/5-3.html

http://www.courts.go.jp/saiban/tetuzuki/syosiki/pdf/rikon_sojo.pdf

http://www.courts.go.jp/about/sihonomado/qa64.html

http://www.courts.go.jp/saiban/qa/qa_kazi/index.html 
Yuki Horie, Ekwiwalencja polskich i japońskich terminów prawnych... 